\title{
IKK $\beta$ inhibition prevents fat-induced beta cell dysfunction in vitro and in vivo in rodents
}

\author{
Aleksandar Ivovic ${ }^{1}$ - Andrei I. Oprescu ${ }^{2}$ - Khajag Koulajian ${ }^{1}$ - Yusaku Mori ${ }^{3}$. \\ Judith A. Eversley ${ }^{1}$ • Liling Zhang ${ }^{4}$ - Rodolfo Nino-Fong ${ }^{5}$ - Gary F. Lewis ${ }^{1,6,7}$. \\ Marc Y. Donath ${ }^{8}$ - Michael Karin ${ }^{9}$ - Michael B. Wheeler ${ }^{1}$ - Jan Ehses ${ }^{10,11}$. \\ Allen Volchuk ${ }^{12}$ - Catherine B. Chan ${ }^{13,14}$ - Adria Giacca ${ }^{1,2,6,7}$
}

Received: 30 March 2017 / Accepted: 16 May 2017 /Published online: 20 July 2017

(C) Springer-Verlag GmbH Germany 2017

\begin{abstract}
Aims/hypothesis We have previously shown that oxidative stress plays a causal role in beta cell dysfunction induced by fat. Here, we address whether the proinflammatory kinase inhibitor of (nuclear factor) $\mathrm{\kappa B}$ kinase $\beta$ (IKK $\beta)$, which is activated by oxidative stress, is also implicated.

Methods Fat (oleate or olive oil) was infused intravenously in Wistar rats for $48 \mathrm{~h}$ with or without the IKK $\beta$ inhibitor salicylate. Thereafter, beta cell function was evaluated in vivo using hyperglycaemic clamps or ex vivo in islets
\end{abstract}

isolated from fat-treated rats. We also exposed rat islets to oleate in culture, with or without salicylate and $4\left(2^{\prime}\right.$ aminoethyl)amino-1,8-dimethylimidazo(1,2-a)quinoxaline; BMS-345541 (BMS, another inhibitor of IKK $\beta$ ) and evaluated beta cell function in vitro. Furthermore, oleate was infused in mice treated with BMS and in beta cell-specific Ikkb-null mice.

Results $48 \mathrm{~h}$ infusion of fat impaired beta-cell function in vivo, assessed using the disposition index (DI), in rats (saline: $1.41 \pm 0.13$; oleate: $0.95 \pm 0.11$; olive oil [OLO]: $0.87 \pm 0.15 ; p<0.01$ for both fats vs saline) and in mice

Aleksandar Ivovic, Andrei I. Oprescu and Khajag Koulajian contributed equally to this study.

Electronic supplementary material The online version of this article (doi:10.1007/s00125-017-4345-9) contains peer-reviewed but unedited supplementary material, which is available to authorised users.

Adria Giacca

adria.giacca@utoronto.ca

1 Department of Physiology, Faculty of Medicine, University of Toronto, Toronto, ON, Canada, M5S 1A8

2 Institute of Medical Science, Faculty of Medicine, University of Toronto, Toronto, ON, Canada

3 Division of Diabetes, Metabolism, and Endocrinology, Showa University School of Medicine, Shinagawa, Tokyo, Japan

4 Division of Cellular and Molecular Biology, Toronto General Research Institute, University Health Network, Toronto, ON, Canada

5 Department of Biomedical Sciences, Ross University School of Veterinary Medicine, Basseterre, St Kitts and Nevis

6 Department of Medicine, Faculty of Medicine, University of Toronto, Toronto, ON, Canada
7 Banting and Best Diabetes Centre, University of Toronto, Toronto, ON, Canada

8 Department of Endocrinology, Diabetes, and Metabolism, University Hospital Basel, Basel, Switzerland

9 Department of Pharmacology, University of California, San Diego, School of Medicine, La Jolla, CA, USA

10 Department of Surgery, Faculty of Medicine, University of British Columbia, Vancouver, BC, Canada

11 Child and Family Research Institute, Vancouver, BC, Canada

12 Keenan Research Centre for Biomedical Science, St Michael's Hospital, Toronto, ON, Canada

13 Department of Agriculture, Food and Nutritional Sciences, Faculty of Agricultural, Life and Environmental Sciences, University of Alberta, Edmonton, AB, Canada

14 Department of Physiology, Faculty of Medicine and Dentistry, University of Alberta, Edmonton, AB, Canada 
(saline: $2.51 \pm 0.39$; oleate: $1.20 \pm 0.19 ; p<0.01$ vs saline) and ex vivo (i.e., insulin secretion, units are pmol insulin islet $^{-1} \mathrm{~h}^{-1}$ ) in rat islets (saline: $1.51 \pm 0.13$; oleate: $1.03 \pm 0.10$; OLO: $0.91 \pm 0.13 ; p<0.001$ for both fats vs saline) and the dysfunction was prevented by co-infusion of salicylate in rats (oleate + salicylate: $1.30 \pm 0.09$; OLO + salicylate: $1.33 \pm 0.23$ ) or BMS in mice (oleate + BMS: $2.25 \pm 0.42)$ in vivo and by salicylate in rat islets ex vivo (oleate + salicylate: $1.74 \pm 0.31$; OLO + salicylate: $1.54 \pm 0.29)$. In cultured islets, $48 \mathrm{~h}$ exposure to oleate impaired beta-cell function ([in pmol insulin islet $\left.{ }^{-1} \mathrm{~h}^{-1}\right]$ control: $0.66 \pm 0.12$; oleate: $0.23 \pm 0.03 ; p<0.01$ vs saline), an effect prevented by both inhibitors (oleate + salicylate: $0.98 \pm 0.08$; oleate + BMS: $0.50 \pm 0.02$ ). Genetic inhibition of IKK $\beta$ also prevented fat-induced beta-cell dysfunction ex vivo ([in pmol insulin islet ${ }^{-1} \mathrm{~h}^{-1}$ ] control saline: $0.16 \pm 0.02$; control oleate: $0.10 \pm 0.02$; knockout oleate: $0.17 \pm 0.04 ; p<0.05$ control saline vs. control oleate) and in vivo (DI: control saline: $3.86 \pm 0.40$; control oleate: $1.95 \pm 0.29$; knockout oleate: $2.96 \pm 0.24 ; p<0.01$ control saline vs control oleate).

Conclusions/interpretation Our results demonstrate a causal role for IKK $\beta$ in fat-induced beta cell dysfunction in vitro, ex vivo and in vivo.

Keywords Beta cell dysfunction · IKK $\beta$ - In vivo · Inflammation $\cdot$ Lipotoxicity $\cdot$ Oleate $\cdot$ Olive oil $\cdot$ Oxidative stress

$\begin{array}{ll}\text { Abbreviations } \\ \text { AMPK } & \begin{array}{l}5^{\prime} \text { Adenosine monophosphate-activated } \\ \text { protein kinase }\end{array} \\ \text { BMS } & \begin{array}{l}4\left(2^{\prime} \text {-Aminoethyl)amino-1,8-dimethylimidazo }\right. \\ (1,2-a) \text { quinoxaline; BMS-345541 }\end{array} \\ \text { COX } & \text { Cyclooxygenase } \\ \text { Cre } & \text { Cre recombinase } \\ \text { DI } & \text { Disposition index } \\ \text { GINF } & \text { Glucose infusion rate } \\ \text { IKB } \alpha & \text { Inhibitor of (nuclear factor) } \mathrm{kB} \alpha \\ \text { IKK } \beta & \text { Inhibitor of (nuclear factor) } \mathrm{kB} \text { kinase } \beta \\ \text { Ikkb beta cell } & \text { Beta cell-specific IKK beta-deficient } \\ & \text { (mouse model) } \\ \text { INOS } & \text { Inducible nitric oxide synthase } \\ \text { IL-1RA } & \text { IL-1 receptor antagonist } \\ \text { MCP-1 } & \text { Monocyte chemoattractant protein 1 } \\ M / I & \text { Insulin sensitivity index (glucose metabolism } \\ & {[M] / \text { plasma insulin [I]) }} \\ \text { OLO } & \text { Olive oil } \\ \text { PGE2 } & \text { Prostaglandin E2 } \\ \text { RIP2 } & \text { Rat insulin } 2 \text { promoter } \\ \text { ROS } & \text { Reactive oxygen species }\end{array}$

\section{Introduction}

NEFA have been shown to both stimulate and impair insulin secretion depending on the duration of beta cell exposure [1]. Prolonged ( $>24 \mathrm{~h}$ ) exposure is inhibitory and involves oxidative stress, endoplasmic reticulum stress and inflammation [1].

Lipotoxic effects on the beta cell, i.e. the decrease in beta cell function and mass induced by chronically elevated NEFA, play a role in the pathogenesis of type 2 diabetes, at least in predisposed individuals [1]. Previously, we demonstrated that oxidative stress mediates fatinduced beta cell dysfunction in vivo in rats [2] and in humans [3]. Oxidative stress activates inhibitor of (nuclear factor) $\kappa \mathrm{B}$ kinase $\beta$ (IKK $\beta$ ), which, by phosphorylating the inhibitor of (nuclear factor) $\kappa \mathrm{B} \alpha(\operatorname{I\kappa B} \alpha)$, activates the transcription factor $\mathrm{NF} \kappa \mathrm{B}$. The effect of $\mathrm{IKK} \beta / \mathrm{NF} \kappa \mathrm{B}$ on beta cell function is controversial. NFKB is important for cell survival and there are reports that $\mathrm{NF} \kappa \mathrm{B}$ is beneficial for glucose-stimulated insulin secretion [4], unless activated by cytokines [5]. However, IKK $\beta$ which induces serine phosphorylation of IRSs [6] in addition to activating $\mathrm{NF}_{\kappa} \mathrm{B}$, decreases beta cell function [7]. It is also controversial whether fat activates $\mathrm{IKK} \beta / \mathrm{NF} \kappa \mathrm{B}$ in beta cells: although fatty acids did not activate NFKB in INS-1 or primary rat beta cells in one study [8], lipotoxicity was associated with NFKB activation, and palmitate-induced apoptosis was inhibited by an IKK $\beta$ inhibitor in INS-1 beta cells in another study [9]. The in vivo effect of fat on beta cell IKK $\beta / \mathrm{NF}$ KB has not been investigated previously.

To address the role of IKK $\beta$ in fat-induced beta cell dysfunction in vivo, rats were infused i.v. with fat to elevate plasma NEFA 50-100\% (elevation seen in obesity [10]) with or without the IKK $\beta$ inhibitor [11] salicylate for $48 \mathrm{~h}$. Monounsaturated fat (oleate or olive oil) was infused, as in our previous study showing a role of oxidative stress in beta cell dysfunction [2]. Although oleate has been found to protect beta cells against palmitate-induced toxicity in in vitro studies [12], the prolonged effect of oleate by itself on beta cell function is mainly inhibitory [2, 13]. After $48 \mathrm{~h}$ infusion, beta cell function was evaluated in vivo using hyperglycaemic clamps, or ex vivo in isolated islets. We also used the specific IKK $\beta$ inhibitor 4(2'-aminoethyl)amino1,8-dimethylimidazo(1,2-a)quinoxaline; BMS-345541 (BMS) [14] in hyperglycaemic clamps performed after $48 \mathrm{~h}$ oleate infusion in mice. In addition, we exposed rat islets for $48 \mathrm{~h}$ to oleate with or without salicylate or BMS in vitro. Last, we performed oleate infusion in beta cellspecific IKK $\beta$-deficient $\left(I k k b^{\Delta \text { beta cell }}\right.$ ) mice, followed by evaluation of beta cell function in vivo using hyperglycaemic clamps or ex vivo in isolated islets. In all these models, IKK $\beta$ inhibition prevented fat-induced beta cell dysfunction. 
Table 1 Plasma NEFA, triacylglycerol, glucose and insulin levels after $48 \mathrm{~h}$ infusions

\begin{tabular}{llllc}
\hline Treatment & NEFA $(\mathrm{mmol} / \mathrm{l})$ & Triacylglycerol $(\mathrm{mmol} / \mathrm{l})$ & Glucose $(\mathrm{mmol} / \mathrm{l})$ & Insulin $(\mathrm{pmol} / \mathrm{l})$ \\
\hline Saline $(n=12)$ & $0.693 \pm 0.026$ & $0.17 \pm 0.019$ & $5.8 \pm 0.2$ & $79 \pm 12$ \\
Oleate $(n=10)$ & $1.050 \pm 0.118^{* *}$ & $0.21 \pm 0.014$ & $5.9 \pm 0.1$ & $72 \pm 13$ \\
OLO $(n=7)$ & $0.925 \pm 0.104^{*}$ & $0.60 \pm 0.063^{* * *}$ & $5.5 \pm 0.2$ & $110 \pm 80$ \\
Oleate + SLY $(n=8)$ & $1.123 \pm 0.168^{* *}$ & $0.25 \pm 0.020$ & $5.2 \pm 0.1$ & $68 \pm 14$ \\
OLO + SLY $(n=11)$ & $1.027 \pm 0.095^{*}$ & $0.54 \pm 0.057^{* * *}$ & $5.0 \pm 0.1$ & $82 \pm 15$ \\
SLY $(n=9)$ & $0.580 \pm 0.095$ & $0.15 \pm 0.024$ & $5.4 \pm 0.1$ & $57 \pm 90$ \\
\hline
\end{tabular}

Data are mean \pm SEM

Rats were treated with: saline; oleate at $1.3 \mu \mathrm{mol} / \mathrm{min}$; OLO (20\% olive oil infusate containing $50 \mathrm{U} / \mathrm{ml}$ heparin) at $5.5 \mu \mathrm{l} / \mathrm{min}$; oleate + salicylate at $0.7 \mu \mathrm{mol} \mathrm{kg} \mathrm{min}^{-1}$; OLO + salicylate; or salicylate only

$* p<0.05, * * p<0.01$ and $* * * p<0.001$ vs saline and salicylate only

SLY, salicylate

\section{Methods}

Animals All procedures were approved by the Animal Care Committee of the University of Toronto and conducted according to the Canadian Council on Animal Care Guidelines and the appropriate sample sizes were determined prior to the studies (see also Electronic supplementary material [ESM]).
Female Wistar rats (250-300 g, corresponding to 9-11 weeks of age, Charles River, Senneville, QC, Canada) were used, as in our previous studies $[2,15]$. Female C57BL/6 mice (22$25 \mathrm{~g}$, corresponding to 14-16 weeks of age, Jackson Laboratory, Bar Harbor, ME, USA) and male RIP2 (rat insulin 2 promoter)-Cre recombinase (Cre) positive or negative $I k k b$ floxed mice were also used [16]. Female wild-type C57BL/6
Fig. 1 Plasma glucose $(\mathbf{a}, \mathbf{b})$, GINF (c, d), insulin (e, f) and Cpeptide (g, h) during two-step hyperglycaemic clamps following $48 \mathrm{~h}$ of oleate or OLO infusion.

$(\mathbf{a}, \mathbf{c}, \mathbf{e}, \mathbf{g})$ Rats were treated with: saline $(n=12)$; oleate at $1.3 \mu \mathrm{mol} /$ $\min (n=10)$; oleate + salicylate at $0.7 \mu \mathrm{mol} \mathrm{kg}{ }^{-1} \min ^{-1}(n=8)$; or salicylate only $(n=9)$. $(\mathbf{b}, \mathbf{d}, \mathbf{f}, \mathbf{h})$ Rats were treated with: saline $(n=12)$; OLO (20\% olive oil infusate containing $50 \mathrm{U} / \mathrm{ml}$ heparin) at $5.5 \mu 1 / \min (n=7)$; OLO + salicylate $(n=11)$; or salicylate only $(n=9)$. Data are mean \pm SEM. $* * p<0.01$ and $* * * p<0.001$ vs all, throughout the clamp. White circles, saline; black circles, oleate; black triangles, oleate + salicylate; white triangles, salicylate; black squares, OLO; black diamonds, OLO + salicylate a

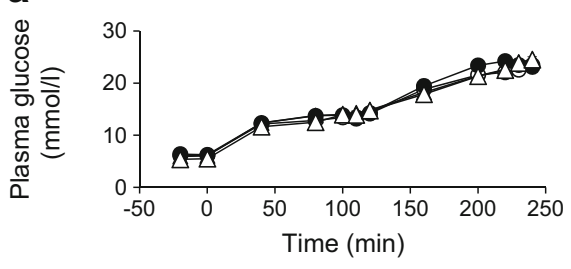

C
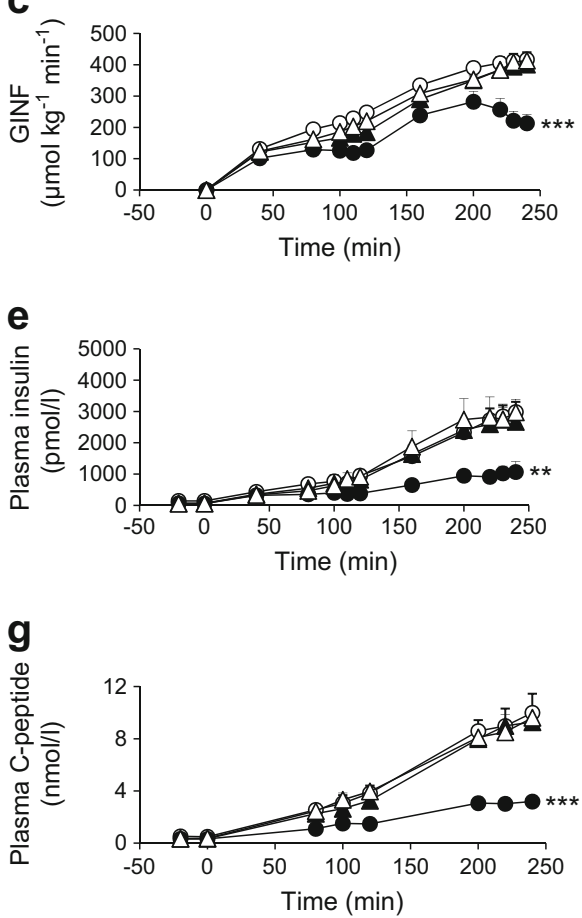

b

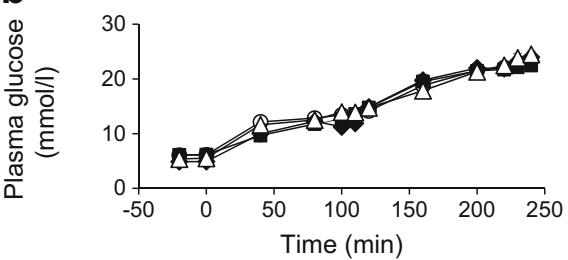

d
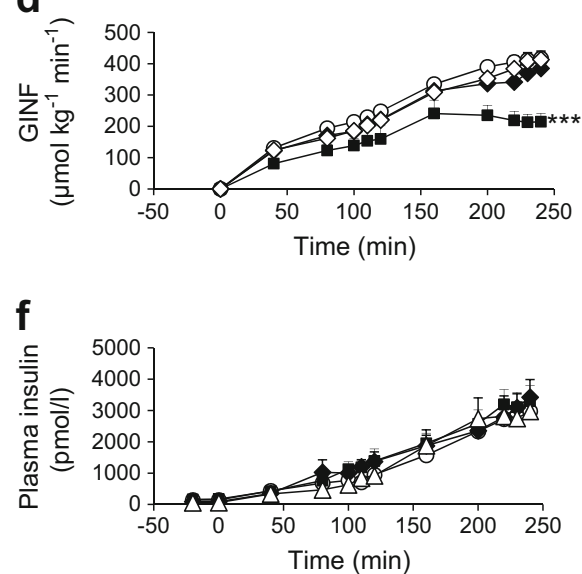

h

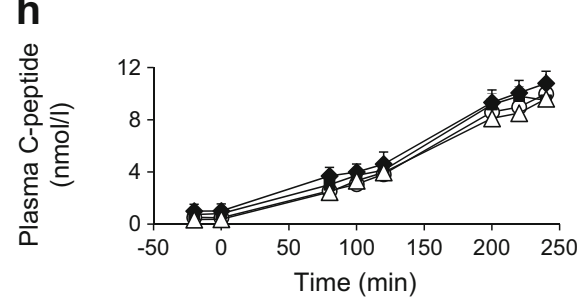


mice underwent the BMS infusion studies. For studies in beta cell-specific $I k k b$-null mice, $I k k b^{\mathrm{F} / \mathrm{F}}$ mice on a $\mathrm{C} 57 \mathrm{BL} / 6$ background were crossed with RIP2-Cre mice (also on a C57BL/6 background) obtained from Jackson Laboratory to generate RIP2-Cre positive or RIP2-negative $I k k b^{F /+}$ mice, which were interbred to generate RIP2-Cre ${ }^{-} I k k b^{\mathrm{F} / \mathrm{F}}$ (floxed controls) and RIP2-Cre ${ }^{+}: I k k b^{\mathrm{F} / \mathrm{F}}\left(I k k b^{\Delta \text { beta cell }}\right)$ mice. These mice were used for experiments at 11-13 weeks of age. Cre-mediated recombination was confirmed by PCR [17].

Surgery and i.v. infusion Surgery was performed under general anaesthesia (isoflurane, to effect). Carotid artery and jugular vein cannulation of rats has been described previously [2, 15]. After 3 days' post-surgical recovery, the rats were randomised to the following $48 \mathrm{~h}$ infusions: (1) $\mathrm{NaCl}$ (154 $\mathrm{mmol} / \mathrm{l} ; 5 \mu \mathrm{l} / \mathrm{min}$ ) as control; (2) fat, either oleate $(1.3 \mu \mathrm{mol} / \mathrm{min})$ prepared as in our previous studies $[2,15]$ or $20 \%$ (vol./vol.) olive oil (OLO; $5.5 \mu \mathrm{l} / \mathrm{min}$ ) prepared as in Dobbins et al [18]; (3) oleate or OLO + salicylate $\left(0.7 \mu \mathrm{mol} \mathrm{kg}^{-1} \mathrm{~min}^{-1}\right.$, the dose that reversed insulin resistance in Park et al [19]); or (4) salicylate only. Olive oil is a triacylglycerol mixture containing $75 \%$ oleate, and $16 \%$ saturated fat. Heparin was added to olive oil to a final concentration of $50 \mathrm{U} / \mathrm{ml}$ to activate lipoprotein lipase, which releases NEFA and glycerol from the triacylglycerol mixture of olive oil. We have shown that BSA, the vehicle for oleate, has no effect on insulin secretion [15, 20]; heparin [21] and glycerol [22] also have no effect. A two-step hyperglycaemic clamp or islet isolation was performed after the infusion period.

Mouse jugular vein cannulation is described in Koulajian et al [20]. In mice, oleate $(0.4 \mu \mathrm{mol} / \mathrm{min}) /$ equivolume saline was infused for $48 \mathrm{~h}$ [20], starting 4-5 days after surgery with or without BMS (0.12 mmol kg ${ }^{-1}$ day $\left.^{-1}\right)$ [14]. After $48 \mathrm{~h}$ infusion, mice received hyperglycaemic clamps. Sampling was through the tail vein.

Hyperglycaemic clamp Insulin secretion was determined by measuring plasma insulin and C-peptide during a two-step (13 and $22 \mathrm{mmol} / \mathrm{l}$ ) hyperglycaemic clamp in rats [2] and a onestep (22 mmol/l) hyperglycaemic clamp in mice [20]. Insulin sensitivity $(M / \mathrm{I}$, where $M$ is glucose metabolism and I is plasma insulin) and beta cell function (disposition index [DI]; units are $\mu \mathrm{mol} \mathrm{kg}{ }^{-1} \mathrm{~min}^{-1}$ glucose/pmol insulin $\times$ nmol Cpeptide) were assessed as described in the ESM.

Hyperinsulinaemic-euglycaemic clamp Insulin sensitivity was determined using the gold-standard technique, i.e. hyperinsulinaemic-euglycaemic clamp [19].

Ex vivo studies Islets of the in vivo infused rats and $I k k b^{\Delta \text { beta cell }}$ mice were isolated and insulin secretion studies were performed as described previously [2]. ELISA for phosphorylated I $\mathrm{B} \alpha$ and active nuclear NFkB (Active Motif, Carlsbad, CA, USA), reac- tive oxygen species (ROS) measurements (see ESM) and RTPCR were also performed in rat islets. Total rat islet RNA was prepared as described previously $[23,24]$ according to the manufacturer's instructions (Qiagen, Hombrechtikon, Switzerland), and was reverse transcribed using random hexamers. Mouse primers for $I l 1 b$, Tnfa (also known as Tnf), monocyte chemoattractant protein 1 (Mcp1; also known as Ccl2), IL-1 receptor antagonist (Illra; also known as Illrn), Tgfb (also known as $T g f b 1)$, the macrophage marker $C d 68$, and cyclooxygenase (Cox)2 (also known as Ptgs2) (see ESM Table 1) from Applied Biosystems (Foster City, CA, USA) were used and quantitative PCR was done with a fluorescein amidite (FAM)based reference dye using commercial TaqMan gene expression assays and the 7500 Fast Real-Time PCR System according to the manufacturer's protocol (Applied Biosystems). Changes in mRNA expression were calculated using difference in $\mathrm{C}_{\mathrm{t}}$ values, and normalised to the housekeeping gene $18 \mathrm{~S}[23,24]$.

Studies in cultured islets Rat islets were cultured for $48 \mathrm{~h}$ in RPMI 1640 without antioxidants, containing $0.4 \mathrm{mmol} / \mathrm{l}$ oleate in $0.5 \%$ NEFA-free BSA with or without $0.25 \mathrm{mmol} / 1$ salicylate [7] or $3 \mu \mathrm{mol} / 1 \mathrm{BMS}$, a dose based on pilot doseresponse studies. Islets were also cultured in control/oleate media with or without the COX-2 inhibitor SC-236
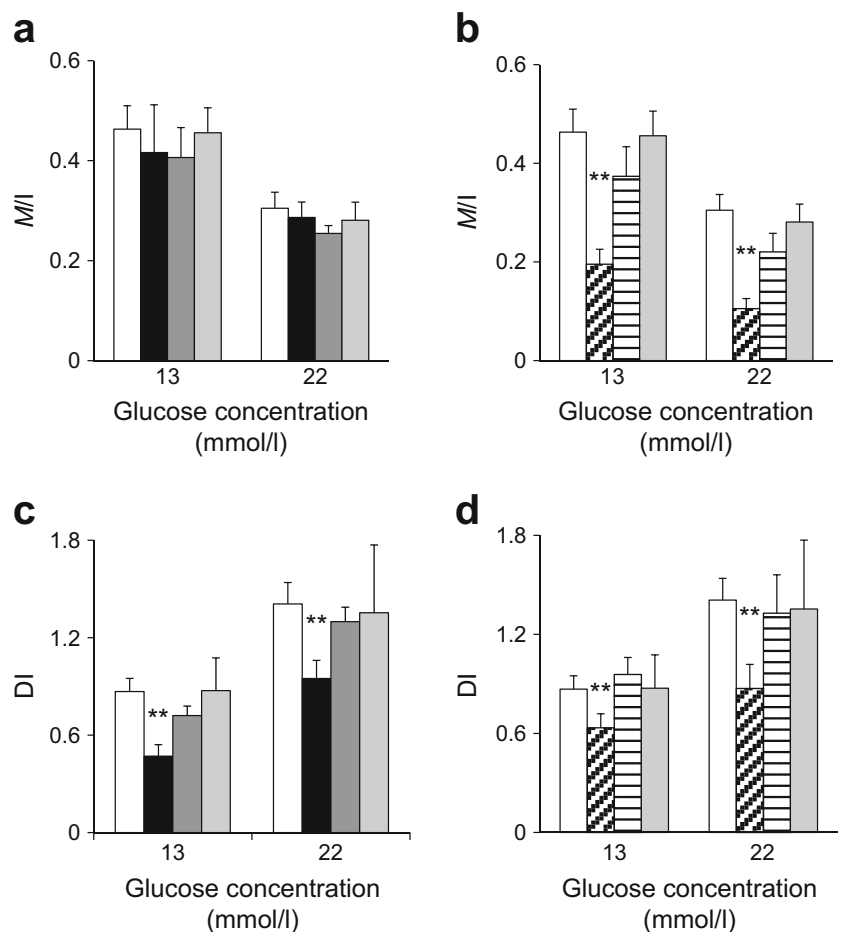

Fig. $2 M / I$ and DI during two-step hyperglycaemic clamps with and without infusion for $48 \mathrm{~h}$ of oleate $(\mathbf{a}, \mathbf{c})$ or OLO $(\mathbf{b}, \mathbf{d})$. See ESM Methods for calculation of these indices. The groups are as described for Fig. 1. Data are mean \pm SEM. $* * p<0.01 \mathrm{vs}$ all groups at the same glucose concentration. White bars, saline; light grey bars, salicylate only. In $(\mathbf{a}, \mathbf{c})$ : black bars, oleate; dark grey bars, oleate + salicylate. In $(\mathbf{b}, \mathbf{d})$ : diagonal striped bars, OLO; horizontal striped bars, OLO + salicylate 
Fig. 3 Insulin secretory response to glucose $(\mathbf{a}, \mathbf{b})$, and quantification of phosphorylated $\mathrm{IkB} \alpha(\mathbf{c}, \mathbf{d})$ and active nuclear $\operatorname{NFkB}(\mathbf{e}, \mathbf{f})$ in freshly isolated islets from fat-infused rats. Groups are as described for Fig. 1 In $(\mathbf{a}, \mathbf{b})$ : saline, $n=16$; oleate, $n=14$; oleate + salicylate, $n=8$; OLO, $n=12$; OLO + salicylate, $n=6$; salicylate only, $n=10$. In (c-f): saline, $n=5-7$; oleate, $n=4-6$; oleate + salicylate, $n=4$ 5; OLO, $n=5-6$; OLO + salicylate, $n=5-8$; salicylate only, $n=4-6$. Data are mean \pm SEM. $* p<0.05$, $* * p<0.01$ and $* * * p<0.001$ vs all (in $\mathbf{a}$ and $\mathbf{b}$, comparison is to all groups at the same glucose concentration). White bars, saline; light grey bars, salicylate. In (a, c e): black bars, oleate; dark grey bars, oleate + salicylate. In (b, d, f): diagonal striped bars, OLO; horizontal striped bars, OLO + salicylate

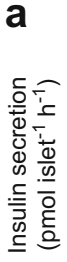

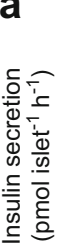

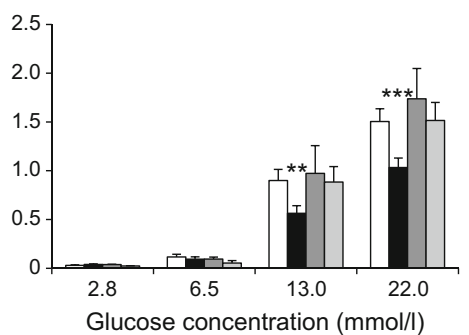

C

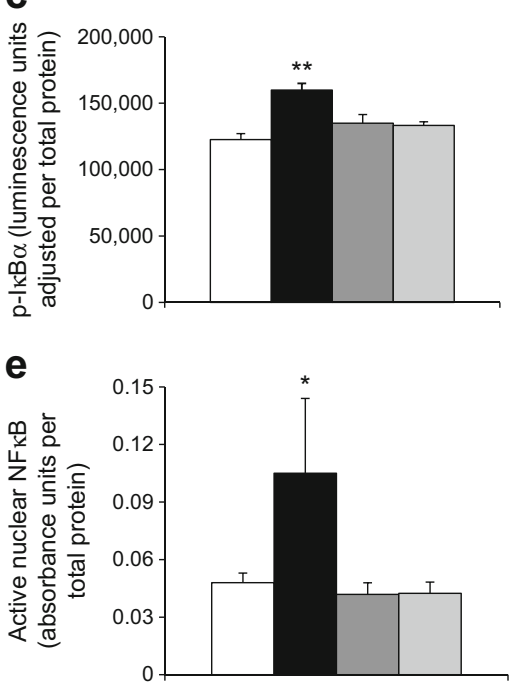

b

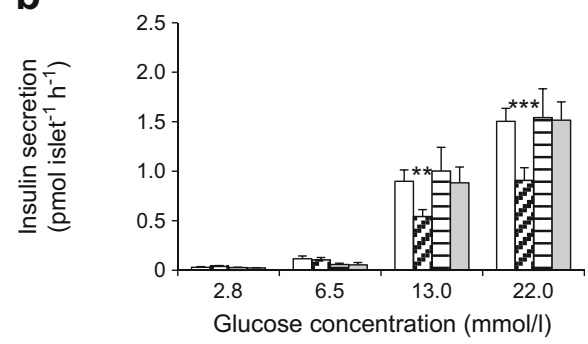

d

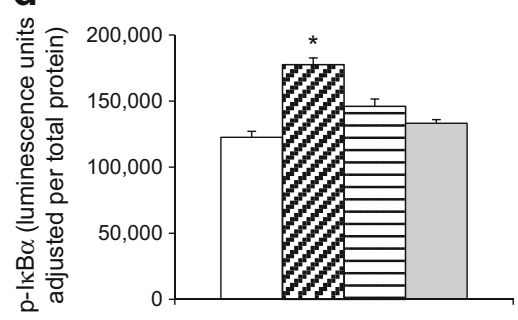

f

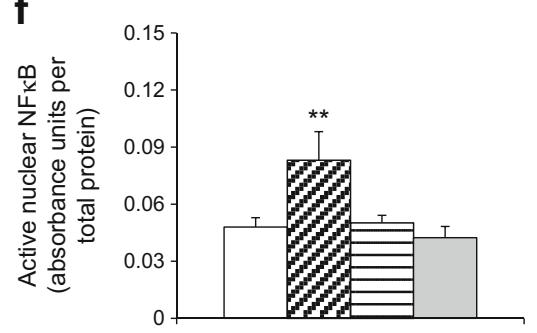

(10 $\mu \mathrm{mol} / 1$, based on Castaño et al [25]) or the COX-1 inhibitor SC-560 (100 $\mu \mathrm{mol} / 1$, based on Smith et al [26]). Thereafter, glucose-stimulated insulin secretion was assessed. Prostaglandin E2 (PGE2) in the medium was measured via ELISA (Enzo Life Sciences, Farmingdale, NY, USA).
Western blots Western blots were performed as previously described [19] using antibody against phospho-Ser307-IRS1 (Millipore, Billerica, MA, USA, 07-247, raised in rabbit, RRID:AB_310463, 1:500), total IKK $\beta$ (Cell Signaling Technology, Danvers, MA, USA, 2370, raised in rabbit,

Table 2 mRNA levels of inflammatory markers in freshly isolated islets of infused rats

\begin{tabular}{|c|c|c|c|c|}
\hline Marker & Saline & Oleate & Oleate + SLY & SLY \\
\hline$I l 1 b$ & $0.82 \pm 0.17(n=8)$ & $2.02 \pm 0.42^{\dagger+,+t, \S \S \S}(n=8)$ & $0.30 \pm 0.12(n=5)$ & $0.10 \pm 0.04^{\dagger}(n=3)$ \\
\hline $\operatorname{Tnfa}(\operatorname{Tnf})$ & $0.58 \pm 0.22(n=6)$ & $1.97 \pm 0.28^{\dagger, \S \S}(n=7)$ & $0.81 \pm 0.46(n=4)$ & $0.08 \pm 0.04(n=3)$ \\
\hline $\operatorname{Mcp} 1(\mathrm{Ccl} 2)$ & $0.76 \pm 0.28(n=6)$ & $5.64 \pm 1.89^{\dagger \dagger, 4+t, \S \S \S}(n=10)$ & $0.52 \pm 0.24(n=5)$ & $0.01 \pm 0.00^{\dagger}(n=3)$ \\
\hline Illra (Illrn) & $1.00 \pm 0.31(n=5)$ & $15.52 \pm 4.67^{\dagger \dagger}(n=10)$ & $2.79 \pm 1.34(n=4)$ & $4.70 \pm 2.79(n=3)$ \\
\hline$T g f b(T g f b 1)$ & $0.85 \pm 0.26(n=7)$ & $2.47 \pm 0.51^{\dagger, \$, \S \S}(n=7)$ & $0.81 \pm 0.37(n=4)$ & $0.54 \pm 0.33(n=4)$ \\
\hline Cd68 & $0.62 \pm 0.14(n=8)$ & $4.21 \pm 1.07^{\dagger \dagger,+4, \S \S}(n=7)$ & $0.54 \pm 0.12(n=4)$ & $0.75 \pm 0.37(n=3)$ \\
\hline $\operatorname{Cox} 2(P \operatorname{tgs} 2)$ & $1.00 \pm 0.10(n=5)$ & $2.66 \pm 0.53^{\dagger+,+4+\S \S \S}(n=9)$ & $0.36 \pm 0.10^{\dagger}(n=3)$ & $0.33 \pm 0.09^{\dagger}(n=4)$ \\
\hline
\end{tabular}

Data are mean \pm SEM

Rats were infused with: saline; oleate; oleate + salicylate; or salicylate only

Units are normalised to a housekeeping gene

Sample size differed between markers as some samples had expression levels that were either undetectable or outliers according to the Grubb's test

${ }^{\dagger} p<0.05,{ }^{\dagger \dagger} p<0.01$ and ${ }^{\dagger \dagger} p<0.001$ vs saline

${ }^{\star} p<0.05,{ }^{\star} p<0.01$ and ${ }^{\star \pm} p<0.001$ vs oleate + salicylate

$\S \S p<0.01$ and ${ }^{\S \S} p<0.001$ vs salicylate alone

SLY, salicylate 
RRID:AB 2122154, 1:100), phospho-Thr172-5' adenosine monophosphate-activated protein kinase (AMPK) $\alpha$ (Cell Signaling Technology, 2535, raised in rabbit, RRID:AB_331250, 1:1000), total AMPK $\alpha$ (Cell Signaling Technology, 2793, raised in mouse, RRID:AB_915794, 1:1000), total I $\mathrm{B} \alpha \alpha$ (Santa Cruz Biotechnology, Dallas, TX, USA, sc-371, raised in rabbit, RRID:AB 2235952, 1:250), $\alpha$-actinin (Cell Signaling Technology, $3134 \mathrm{~S}$, raised in rabbit, RRID:AB_2223798, 1:1000), $\beta$-actin (Abcam, Cambridge, UK, ab6276, RRID:AB_2223210, raised in mouse, 1:10,000) or $\gamma$-tubulin (Sigma-Aldrich, St Louis, MO, USA, T6557, RRID:AB_477584, raised in mouse, 1:1000) (see also ESM). The antibodies had been validated in previous studies carried out in the laboratory (see ESM).

Plasma assays Plasma glucose in rats was measured on a Beckman Analyser II (Beckman, Fullerton, CA, USA) and in mice was measured on a HemoCue Glucose 201 Analyser (HemoCue, Brea, CA, USA). Plasma NEFA were measured with an enzymatic colorimetric kit (Wako Industries, Neuss, Germany). Radioimmunoassays specific for rat/ mouse insulin and C-peptide (Linco, St Charles, MO, USA) were used to determine their plasma concentrations.
Plasma triacylglycerol levels were measured by a colorimetric kit (Boehringer Mannheim, Laval, QC, Canada).

Statistics Data are means \pm SEM. One-way non-parametric ANOVA for repeated measurements followed by Tukey's test was used to compare treatments. Calculations were performed using SAS version 8.0 (Cary, NC, USA).

\section{Results}

Hyperglycaemic clamp in rats Rats were infused i.v. with saline, oleate or OLO, with or without the IKK $\beta$ inhibitor salicylate. After $48 \mathrm{~h}$ infusion, levels of plasma NEFA were $\sim 1.5$-fold higher with oleate or OLO and triacylglycerol levels were elevated by OLO (Table 1). Oleate, OLO or salicylate did not affect plasma glucose or insulin (Table 1). Following the $48 \mathrm{~h}$ infusions, we evaluated beta cell function in vivo using two-step hyperglycaemic clamps $(13 \mathrm{mmol} / \mathrm{l}$ and $22 \mathrm{mmol} / \mathrm{l}$, Fig. 1a, b). The glucose infusion rate (GINF) necessary to maintain the clamp was lower with oleate or OLO, suggesting reduced insulin secretion and/or sensitivity (Fig.
Fig. 4 Plasma glucose (a), GINF (b), plasma insulin (c), C-peptide (d), $M / \mathrm{I}(\mathbf{e})$ and DI (f) during hyperglycaemic clamps in mice treated for $48 \mathrm{~h}$ with: saline $(n=7)$; oleate, $0.4 \mu \mathrm{mol} / \mathrm{min}$ $(n=6)$; oleate + BMS,

$0.12 \mathrm{mmol} \mathrm{kg}^{-1} \mathrm{day}^{-1}(n=5)$; or BMS only $(n=3)$. Data are mean \pm SEM. $* * p<0.01$ vs all; ${ }^{\dagger} p<0.05$ vs saline; ${ }^{\ddagger} p<0.05$ vs oleate. White circles/bars, saline; black circles/bars, oleate; black triangles/dark grey bars, oleate + BMS; white triangles/light grey bars, BMS only a

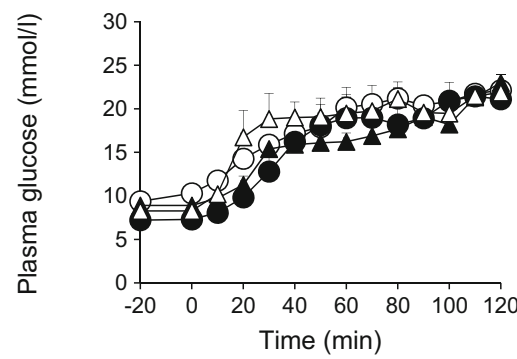

C

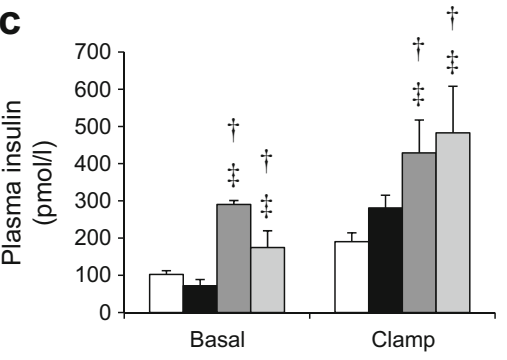

e

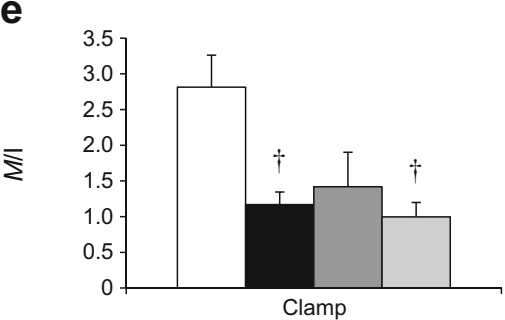

b
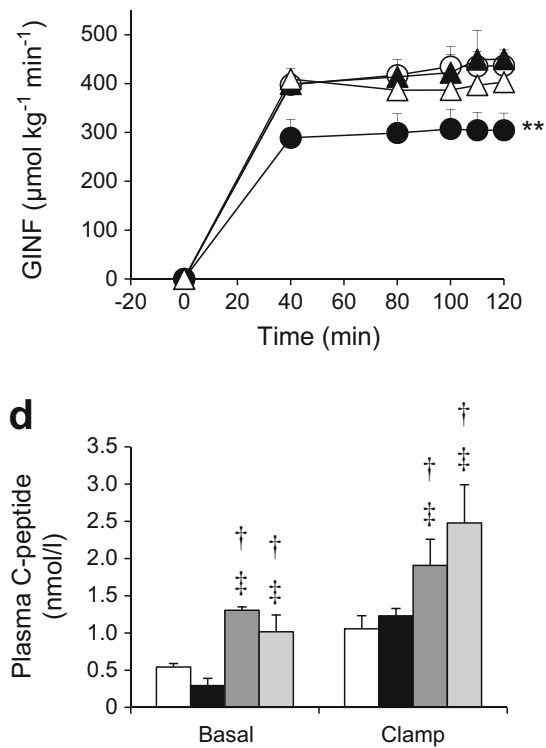

f

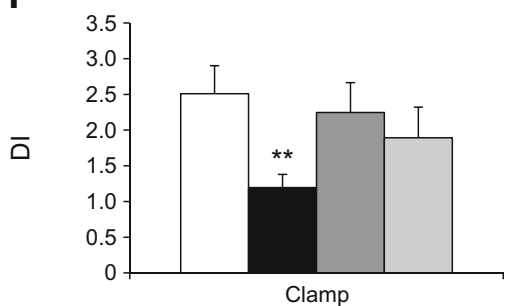


1c, d). With oleate + salicylate or OLO + salicylate, GINF was similar to control (Fig. 1c, d).

Clamp plasma insulin was lower with oleate infusion and was restored with oleate + salicylate, whereas insulin was not different from control with OLO and OLO + salicylate (Fig. 1e, f). Clamp C-peptide showed the same pattern as insulin (Fig. 1g, h), indicating unchanged absolute insulin secretion in OLO-treated groups.

The insulin sensitivity index $(M / \mathrm{I}=\mathrm{GINF} /$ insulin [27]) was not affected by oleate (Fig. 2a), as previously found in the same model [2, 15], and was also unaffected by salicylate. With OLO, $M / \mathrm{I}$ was reduced, indicating insulin resistance (Fig. 2b). The decrease in $M / \mathrm{I}$ was prevented by salicylate. The evaluation of beta cell function in vivo should take into account the ambient insulin sensitivity, as normal beta cells increase insulin secretion in response to insulin resistance along a hyperbola, characterised by a constant DI [28]. The DI is an established index of beta cell function [28] that we have previously validated in rodents $[20,24]$. The DI was impaired in both oleate and OLO groups (Fig. 2c, d), indicating reduced beta cell function; the impairment was completely prevented by salicylate. Salicylate alone had no effect on DI.

Hyperinsulinaemic-euglycaemic clamp When evaluated by hyperinsulinaemic-euglycaemic clamp, insulin sensitivity tended to be decreased by oleate $(n=4)$, and was significantly decreased by OLO $(n=3)$ compared with saline $(n=4)$ (ESM Fig. 1).

Ex vivo studies in rat islets Glucose-stimulated insulin secretion from islets isolated from rats i.v. infused with oleate or OLO was markedly impaired, but secretion was restored with salicylate (Fig. 3a, b). Oleate or OLO increased phosphorylated $I \kappa B \alpha$ (Fig. 3c, d) and active nuclear NFkB (Fig. 3e, f), effects that were not apparent in the presence of salicylate.

Oleate increased the levels of islet mRNA for $I l 1 b, \operatorname{Tnfa}$, Mcp 1, Il1 ra, Tgfb, Cd68 and Cox2; the effect of oleate was prevented by salicylate (Table 2). Interestingly, salicylate alone decreased these markers. The signal for mRNA of Inos (also known as Nos2; encoding inducible nitric oxide synthase [INOS]) mRNA was undetectable in all groups. Oleate $(n=6)$ increased islet ROS compared with saline $(n=5)$; however, ROS levels were not reduced by adding salicylate to oleate $(n=8)$, and salicylate alone had no effect $(n=4)$ (ESM Fig. 2).

Hyperglycaemic clamp in mice We used 48 h oleate infusion in mice, with or without BMS, which is a much more potent and specific IKK $\beta$ inhibitor than salicylate, at a dose previously found to inhibit IKK $\beta$ in vivo [14]. After the $48 \mathrm{~h}$ infusion and prior to the hyperglycaemic clamp the groups treated with oleate had higher plasma NEFA (oleate $1.205 \pm 0.156 \mathrm{mmol} / \mathrm{l} ;$ oleate + BMS $1.177 \pm 0.136 \mathrm{mmol} / \mathrm{l})$ than the groups infused with saline $(0.761 \pm 0.206 \mathrm{mmol} / \mathrm{l})$ or BMS alone $(0.689 \pm 0.070 \mathrm{mmol} / \mathrm{l})$. The glucose level was raised to $22 \mathrm{mmol} / \mathrm{l}$ in all groups (Fig. 4a). The GINF necessary to maintain the clamp was lower in oleate-infused animals but was similar to saline with oleate + BMS (Fig. 4b). Clamp insulin and C-peptide were not lower in oleate-treated mice than in control mice (Fig. 4c, d), in contrast to our oleate model in rats, but similar to our previous studies in mice [20] and our olive oil model in rats. Accordingly, the sensitivity index $M / \mathrm{I}$ [27] was lower in oleate-treated mice (Fig. 4e). Basal and clamp insulin and C-peptide levels were higher in the groups treated with BMS. BMS had no significant effect on $M / \mathrm{I}$ when added to oleate but on its own decreased $M / \mathrm{I}$. DI was decreased with oleate infusion, whereas BMS completely prevented the oleate-induced decrease. BMS alone had no effect on DI (Fig. 4f).

a

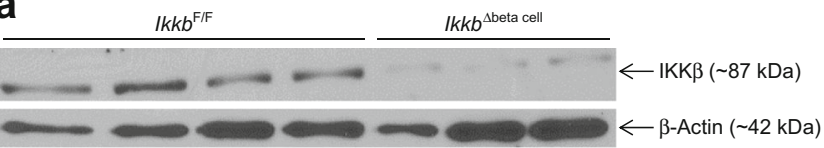

b
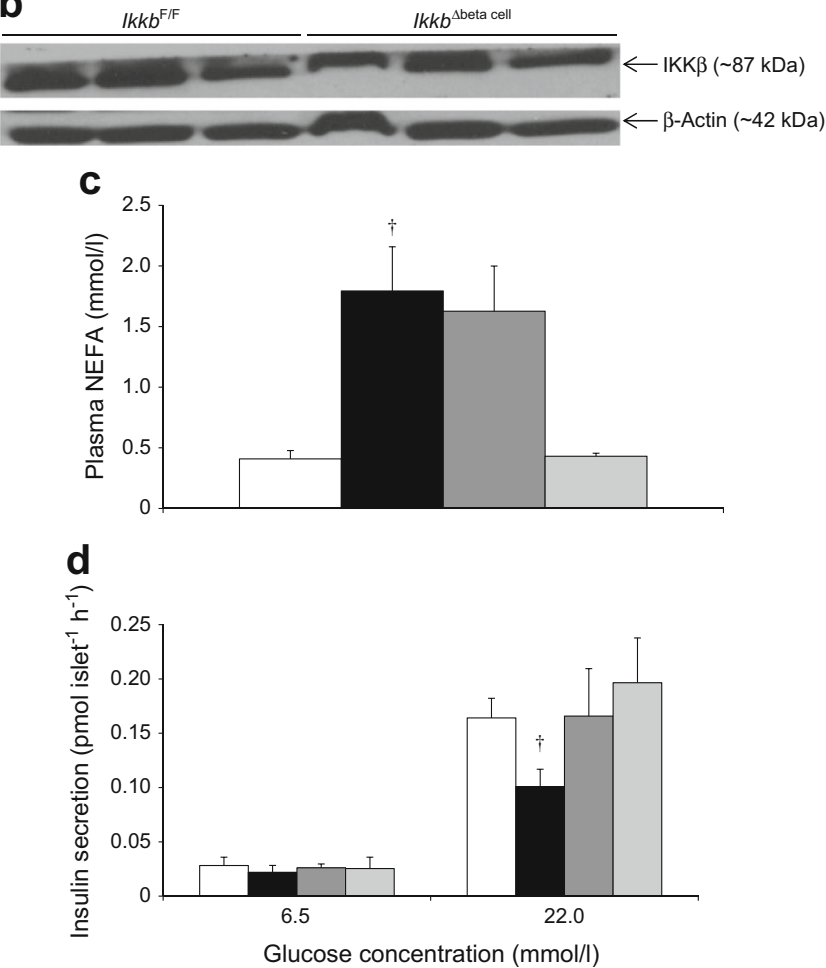

Fig. 5 IKK $\beta$ protein levels in islets (a) and hypothalamus (b) of $I k k b^{\Delta \text { beta cell }}$ mice and floxed controls $\left(I k k b^{\mathrm{F} / \mathrm{F}}\right)$. Each lane represents islets pooled from two mice of the same genotype (a) or one hypothalamus taken from an individual mouse (b). Plasma NEFA (c) and insulin secretory response to glucose of freshly isolated islets of $I k k b^{\mathrm{F} / \mathrm{F}}$ and $I k k b^{\Delta \text { beta }}$ ${ }^{\text {cell }}$ mice (d) following $48 \mathrm{~h}$ oleate $(0.4 \mu \mathrm{mol} / \mathrm{min})$ or saline infusion. Control + saline, $n=8$; control + oleate, $n=7 ; I k k b^{\Delta \text { beta cell }}+$ oleate, $n=5$; Ik k $b^{\Delta \text { beta cell }}+$ saline, $n=9$. Data are mean $\pm \mathrm{SEM}^{\dagger} p<0.05 \mathrm{vs}$ control + saline. White bars, control + saline; black bars, control + oleate; dark grey bars, $I k k b^{\Delta \text { beta cell }}+$ oleate; light grey bars, Ikkb $b^{\Delta \text { beta cell }}+$ saline 
Studies in beta cell-specific IKK $\beta$-deficient mice We also used $I k k b^{\Delta \text { beta cell }}$ and littermate floxed control mice to determine whether genetic silencing of IKK $\beta$ protects from fatinduced beta cell dysfunction ex vivo and in vivo. $I k k b$ deletion in islets of $I k k b^{\Delta \text { beta cell }}$ mice was confirmed by immunoblotting (Fig. 5a) and there was a suggestion of partial deletion in the hypothalamus (Fig. 5b). There was no significant difference in weight between $\sim 13$ week old control $(29.7 \pm 0.7 \mathrm{~g}$, $n=14)$ and $I k k b^{\Delta \text { beta cell }}(28.5 \pm 0.8 \mathrm{~g}, n=13)$ mice. Oleate infusion for $48 \mathrm{~h}$ elevated plasma NEFA approximately threefold (Fig. 5c). Glucose-stimulated insulin secretion from islets isolated from oleate-infused controls was impaired and this impairment was prevented in $I k k b^{\Delta \text { beta cell }}$ mice (Fig. 5d).

Before hyperglycaemic clamping, NEFA were elevated approximately twofold in the oleate-infused groups (Fig. 6a). During hyperglycaemic clamps, the decreased $M / \mathrm{I}$ found in oleate-infused controls was not observed in $I k k b^{\Delta \text { beta cell }}$ mice (Fig. 6b), which may be explained by partial deletion of hypothalamic $I k k b$ driven by RIP2. Importantly, $I k k b^{\Delta \text { beta cell }}$ mice were protected from the decrease in DI induced by oleate in controls (Fig. 6c).

In vitro studies in islets To completely rule out that the effect of salicylate or BMS on beta cell dysfunction was mediated by systemic effects, we performed in vitro studies. Rat islets were cultured for $48 \mathrm{~h}$ in control or oleate-containing medium, with or without salicylate. Oleate decreased glucose-stimulated insulin secretion, and salicylate prevented this decrease (Fig. 7a).

Oleate decreased total IKB $\alpha$ (a marker of IKK $\beta$ activity as phosphorylated IKB $\alpha$ is degraded) and the decrease was prevented with salicylate (Fig. 7b). Salicylate is known to activate AMPK by preventing its dephosphorylation [29] and AMPK activation can result in IKK $\beta$ inhibition [30], though salicylate has also been reported to directly inhibit IKK $\beta$ [11]. There was a tendency for oleate to decrease phosphorylation of AMPK, which appeared to be prevented with salicylate, but there was no significant effect (Fig. 7c). BMS, which inhibits IKK $\beta$ in AMPK $\alpha$-null cells [31], prevented oleate-induced beta cell dysfunction similar to salicylate (Fig. 7d).

The IKK $\beta / \mathrm{NF} \kappa \mathrm{B}$ pathway can mediate oleate-induced beta cell dysfunction by at least three mechanisms: (1) impairment of beta cell insulin signalling via serine phosphorylation of IRS [6]; (2) increase in COX-2-derived PGE2 [32]; and (3) production of NO through induction of INOS [33]. However, Inos mRNA was undetectable in our islets in the ex vivo studies. Oleate increased ser307-phosphorylated IRS-1 in cultured islets, an effect prevented by salicylate (Fig. 8a). Oleate also increased PGE2 release in media and this was prevented by salicylate (Fig. 8b). We also treated islets with the COX-2 inhibitor SC-236, which prevented the secretory defect induced by oleate (Fig. 8c), whereas the COX-1 inhibitor SC-560 did not (insulin secretion values at $22 \mathrm{mmol} / \mathrm{l}$ glucose relative to
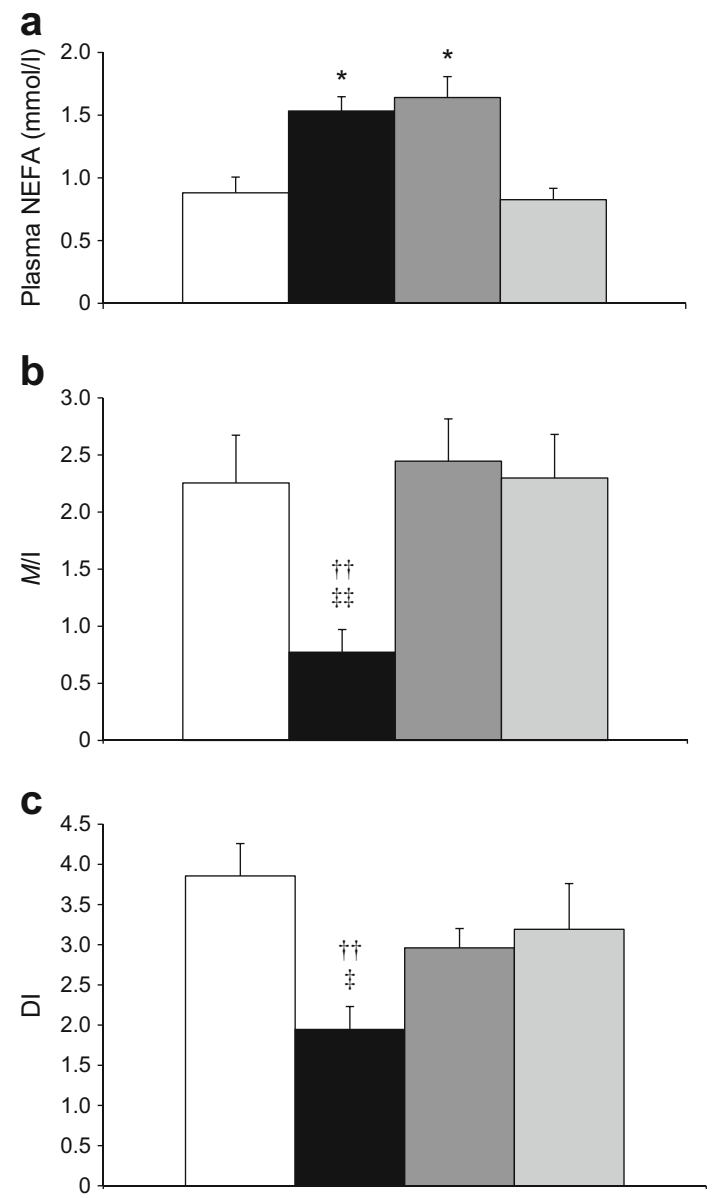

Fig. 6 NEFA levels prior to hyperglycaemic clamp (a), M/I (b) and DI (c) during hyperglycaemic clamps in $I k k b^{\mathrm{F} / \mathrm{F}}$ (control) and $I k k b^{\Delta \text { beta cell }}$ mice following $48 \mathrm{~h}$ oleate $(0.4 \mu \mathrm{mol} / \mathrm{min})$ or saline infusion. Control + saline, $n=8$; control + oleate, $n=7 ; I k k b^{\Delta \text { beta cell }}+$ oleate, $n=8 ; I k k b^{\Delta \text { beta cell }}+$ saline, $n=5$. Data are mean \pm SEM. ${ }^{*} p<0.05$ vs control + saline and $I k k b^{\Delta \text { beta cell }}+$ saline; ${ }^{\dagger \dagger} p<0.01$ vs control + saline; ${ }^{\ddagger} p<0.05$ and ${ }^{\dagger \dagger} p<0.01$ vs $I k k b^{\Delta \text { beta cell }}+$ oleate. White bars, control + saline; black bars, control + oleate; dark grey bars, $I k k b^{\Delta \text { beta cell }}+$ oleate; light grey bars, $I k k b^{\Delta \text { beta cell }}+$ saline

control: control $=1.00 \pm 0.33(n=4)$; oleate $=0.59 \pm 0.17(n=$ 4); oleate + SC-560 $=0.14 \pm 0.06(n=3)$; SC-560 $=0.51(n=2)$.

\section{Discussion}

We examined the effects of prolonged NEFA exposure with or without IKK $\beta$ inhibitors on beta cell function in vivo, ex vivo and in vitro. We used our in vivo models of lipotoxicity in rats [2, 15] and mice [20]. These are models of beta cell dysfunction, as beta cell mass is not decreased by $48 \mathrm{~h}$ fat infusion [20,24] and apoptosis is not increased [34]. During hyperglycaemic clamps in vivo, both insulin and C-peptide levels were lower in rats treated with oleate, indicating reduced insulin secretion; reduced glucose-stimulated insulin secretion was also found in isolated islets ex vivo. With olive oil, glucose-stimulated insulin secretion ex vivo was reduced but insulin and C-peptide levels (indices of 


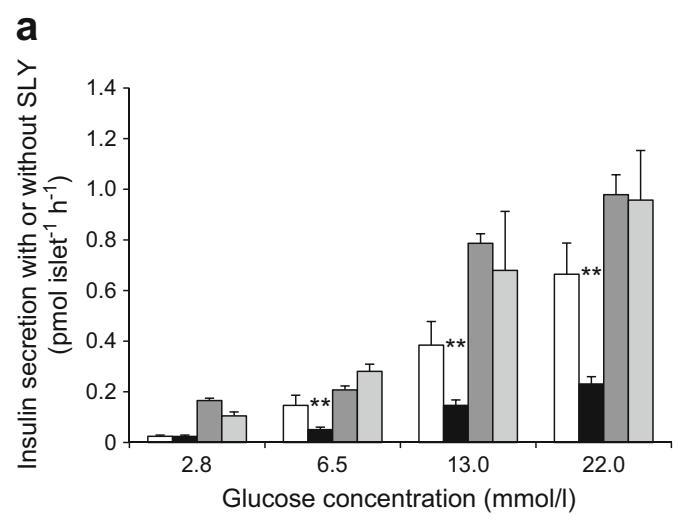

\section{b}

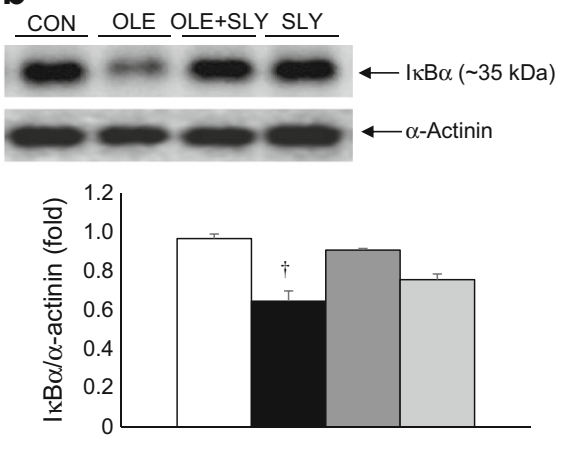

C
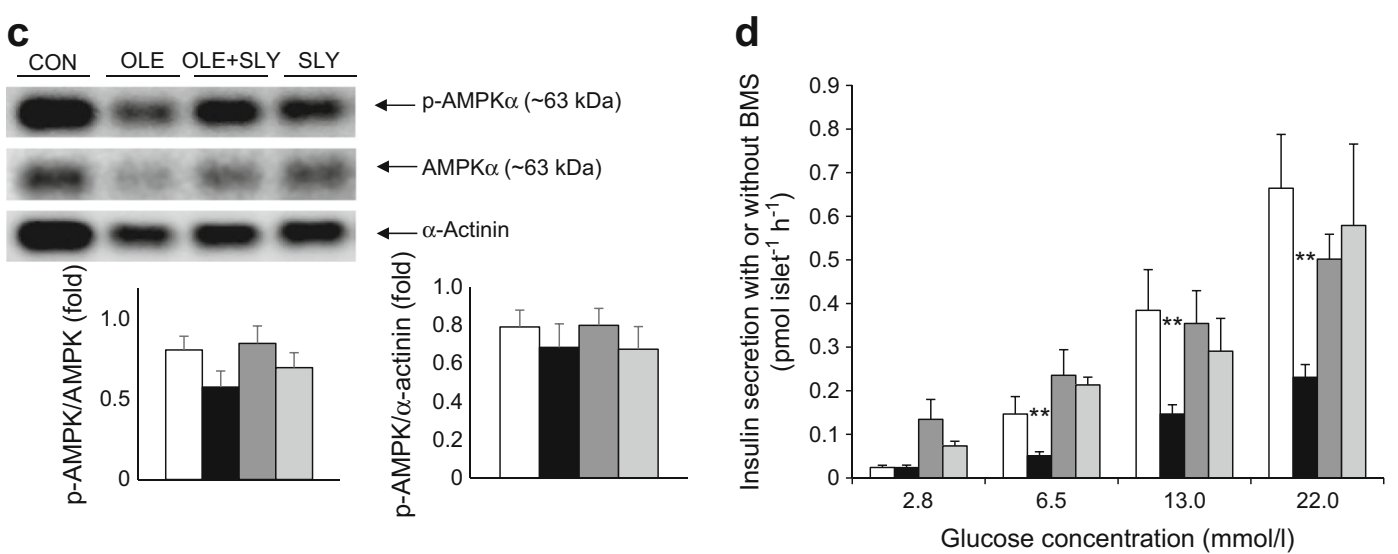

Fig. 7 Levels of insulin secretion (a), IKB $\alpha(\mathbf{b})$ and phosphorylated AMPK $\alpha$ level (c) in islets exposed for $48 \mathrm{~h}$ to control or oleate with/without salicylate. Control, $0.5 \%$ NEFA-free BSA in medium: (a) $n=7$, (b) $n=7$, (c) $n=8$. Oleate, $0.4 \mathrm{mmol} / 1$ in $0.5 \%$ NEFA-free BSA: (a) $n=14$, (b) $n=8,(\mathbf{c}) n=7$. Oleate + salicylate, $0.25 \mathrm{mmol} / 1:$ (a) $n=10$, (b) $n=7$, (c) $n=8$. Salicylate only, in BSA: (a) $n=7$, (b) $n=4$, (c) $n=6$. (d) Insulin secretion in islets exposed to oleate for $48 \mathrm{~h}$ with/without BMS.

absolute insulin secretion) during hyperglycaemic clamps were unaffected. The different absolute insulin secretion between oleate and olive oil is explained by the effect of olive oil to induce a greater degree of insulin resistance. This was demonstrated using hyperinsulinaemic-euglycaemic clamps, which are the goldstandard assessment for insulin sensitivity in vivo. In vivo, the beta cell compensates for insulin resistance by increasing secretion. In the absence of insulin resistance, absolute insulin secretion corresponds to DI. However, in the presence of insulin resistance, DI rather than absolute insulin secretion should be taken as a measure of beta cell function, which includes the ability of the beta cell to compensate for insulin resistance. DI was impaired by both oleate and olive oil, showing a decrease in beta cell function with both types of fat, consistent with the ex vivo results with islets. The different effects of oleate and olive oil on insulin sensitivity may reflect the amount of saturated fat in olive oil (16\%) and/or the plasma triacylglycerol elevation induced by olive oil [35].

Our results showing that fat-induced beta cell dysfunction was prevented by salicylate in vivo and ex vivo in isolated
Control, $n=7$; oleate, $n=14$; oleate $+\mathrm{BMS}, 3 \mu \mathrm{mol} / 1, n=10$; BMS only, in BSA, $n=7$. Data are mean \pm SEM. ${ }^{* * *} p<0.01$ vs all; ${ }^{\dagger} p<0.05$ vs control. White bars, control; black bars, oleate. In (a-c): dark grey bars, oleate + salicylate; light grey bars, salicylate. In (d): dark grey bars, oleate + BMS; light grey bars, BMS. CON, control; OLE, oleate; SLY, salicylate

islets suggest a role for inflammatory pathways involving IKK $\beta$ in lipid-induced beta cell dysfunction.

Inflammatory pathways are known to be activated in beta cell glucotoxicity [36] and may enhance lipotoxicity [37]. Our previous results show that oxidative stress plays a causal role in beta cell dysfunction induced by monounsaturated fat [2]. ROS are known activators of IKK $\beta$ which, in addition to phosphorylating I $\kappa \mathrm{B} \alpha$ and thereby activating NFkB, phosphorylates IRS, thus inhibiting insulin signalling. In our ex vivo study, salicylate prevented the increase in phosphorylated $\mathrm{I} \kappa \mathrm{B} \alpha$ and nuclear active NFKB induced by oleate or olive oil, although, interestingly, salicylate alone had no effect at this dose, as previously seen in the liver [19]. An increase in ROS was induced by oleate, but salicylate did not prevent this effect. This suggests IKK $\beta$ is a downstream effector required for the previously demonstrated effect of oxidative stress to induce beta cell dysfunction [2]. IKK $\beta$ activation could also be unrelated to oxidative stress in the case of olive oil, which contains saturated fat. Saturated fatty acids can activate IKK $\beta$ via toll-like receptors (TLR) 2 and 4. Tlr4-null mice are 
Fig. 8 Serine phosphorylated IRS-1 (a) and PGE2 levels (b) in cultured islets exposed for $48 \mathrm{~h}$ to oleate or vehicle control with/without salicylate. Control, $0.5 \%$ NEFA-free BSA in medium: (a) $n=5$, (b) $n=5$. Oleate, $0.4 \mathrm{mmol} / \mathrm{l}$ in $0.5 \%$ NEFA-free BSA: (a) $n=5$, (b) $n=5$. Oleate + salicylate, $0.25 \mathrm{mmol} / \mathrm{l}:$ (a) $n=5$, (b) $n=6$. Salicylate only, in BSA: (a) $n=5$, (b) $n=5$. (c) Insulin secretion in control or oleate with/without the COX-2 inhibitor SC-236

$(10 \mu \mathrm{mol} / \mathrm{l})$. Control, $n=11$; oleate, $n=10$; oleate + SC-236, $n=9$; SC-236 only, in BSA, $n=9$. Data are mean \pm SEM. $* p<0.05$ and ${ }^{* *} p<0.01$ vs all; ${ }^{\dagger} p<0.05$ vs control. White bars, control; black bars, oleate. In $(\mathbf{a}, \mathbf{b})$ : dark grey bar, oleate + salicylate; light grey bars, salicylate. In (c): dark grey bars, oleate + SC-236; light grey bars, SC-236. CON, control; OLE, oleate; SLY, salicylate
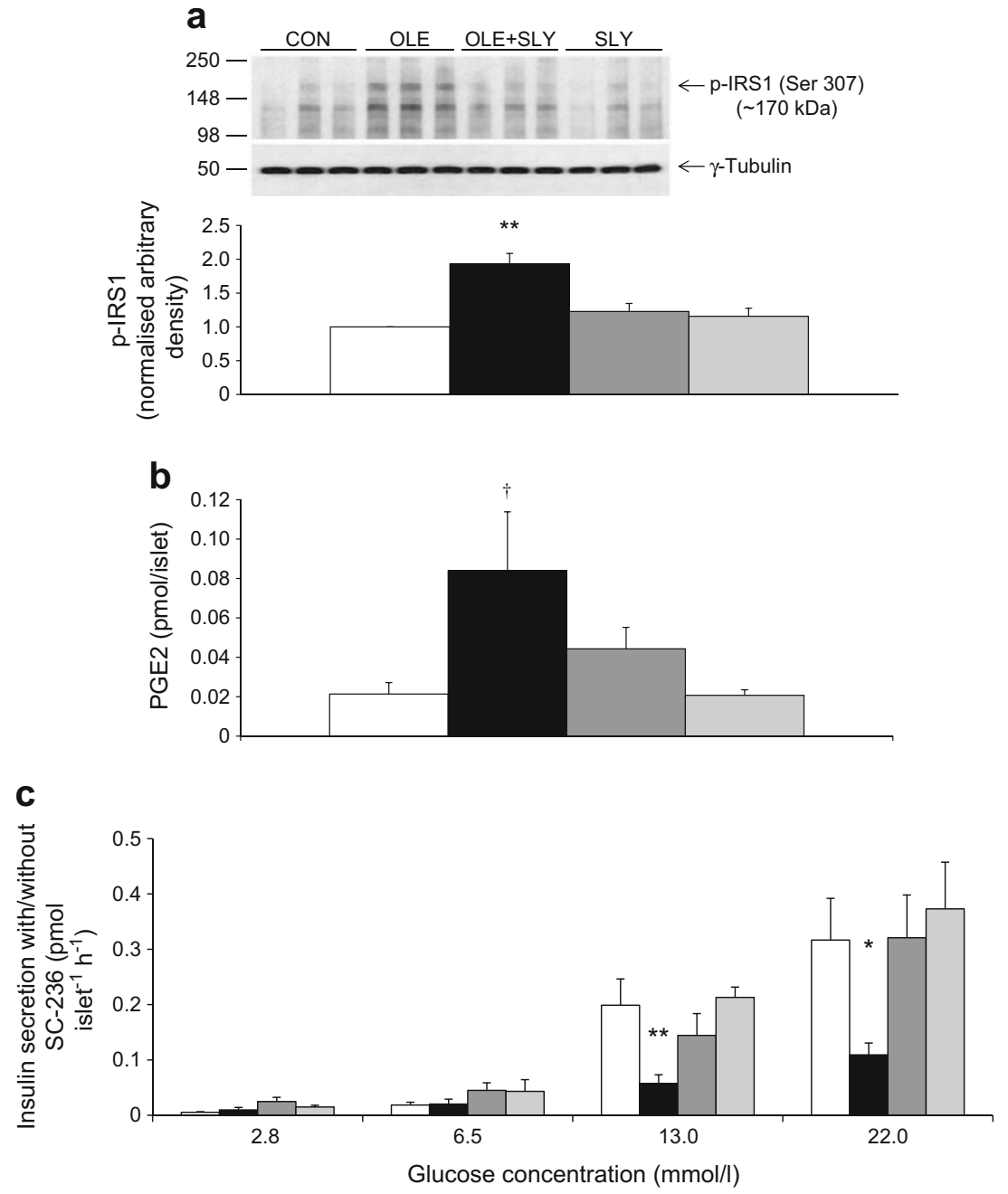

protected from beta cell dysfunction induced by palmitate [38] and Tlr2-null mice are protected from beta cell dysfunction induced by high-fat diet [23]. Although saturated fat is believed to exert a more deleterious effect on beta cells than unsaturated fat, this is mostly based on in vitro data because, until recently, palmitate infusion has been a challenge [38].

Salicylate has previously been found to restore glucosestimulated insulin secretion in an in vitro glucotoxicity model [7]. Although not all studies are concordant [39], the majority report that salicylate improves beta cell function in humans [40-42]. This effect was initially attributed to inhibition of COX-2 [32], the gene for which is controlled by NFKB, and the consequently decreased synthesis of PGE2, a prostaglandin which inhibits insulin secretion. In addition to inhibiting Cox 2 transcription via NFKB, salicylate is a direct inhibitor of both COX-1 and COX-2 [43], and an activator of AMPK [29]. Salicylate did not likely protect against beta cell dysfunction through COX-1 inhibition as a COX-1 inhibitor did not prevent oleate-induced beta cell dysfunction. AMPK phosphorylation, however, did tend to decrease with oleate and this decrease was prevented by salicylate, which raises the question as to whether the protective effect of salicylate was mediated in part by AMPK activation. The effect of AMPK on insulin secretion is generally considered to be inhibitory [44]; however, AMPK may also deplete islet fat [45] and inhibit $\operatorname{IKK} \beta$ [30]. To further implicate IKK $\beta$ in the effect of oleate to decrease beta cell function, we also used BMS, an inhibitor that, to our knowledge, has not been reported to activate AMPK; we obtained the same results for beta cell function as with salicylate both in vitro and in vivo. Importantly, the effect of IKK $\beta$ to mediate fat-induced beta cell dysfunction is also supported by our ex vivo and in vivo data using a genetic inhibition model, the $I k k b^{\Delta \text { beta cell }}$ mouse.

In mice, however, two important differences from the rat studies were noted. First, $48 \mathrm{~h}$ exposure to oleate induced marked insulin resistance in mice in accordance with our previously published data [20]. Besides species difference, the reason behind this finding may be the strain of mice, as C57BL/6 mice are very susceptible to fat-induced insulin resistance [46]. Oleate infusion, which induced insulin resistance in mice, did not result in lower absolute insulin secretion 
during the clamp, but decreased beta cell function (DI), similar to our results with olive oil in rats. Second, BMS did restore DI but did not affect oleate-induced insulin resistance, as it likely effected a decrease in insulin sensitivity itself, which resulted in increased plasma insulin and C-peptide during clamps. Decreased insulin sensitivity with an IKK $\beta$ inhibitor may be dose related and due to the inhibition of COX-2derived prostaglandins that increase insulin action [47].

The mechanisms whereby IKK $\beta$ inhibition prevents fatinduced beta cell dysfunction deserve further study. However, both upregulation of insulin signalling and COX-2 inhibition are plausible mechanisms, as suggested by two lines of evidence. First, salicylate prevented serine phosphorylation of IRS, which is known to decrease insulin-induced tyrosine phosphorylation (i.e. insulin signalling). Beta cell insulin signalling is known to be important for beta cell function [48]. Second, salicylate prevented the oleate-induced PGE2 production and a COX-2 inhibitor mimicked the effect of salicylate. Previously, the effect of COX-2 on beta cell function has been studied mainly in the context of cytokine exposure, with contrasting results, presumably due to $\mathrm{COX}-1$ vs $\mathrm{COX}-2$ specificity of the inhibitors used [32,49]. Also, the effects of exposure to COX-2 products yielded variable results among laboratories $[49,50]$ but a dose-dependent inhibitory effect $[49,50]$ suggests COX-2 may be implicated in decreasing beta cell function. As oleate increased Ill ra gene expression to a greater extent than that of $111 \mathrm{~b}$, the increase in Cox 2 mRNA expression is likely due to an oxidative stress-induced activation of IKK $\beta$, independent of IL-1 $\beta$. Nonetheless, salicylate did prevent upregulated gene expression of cytokines and chemokines, which may have contributed to beta cell dysfunction by further activating IKK $\beta$ and possibly other inflammatory pathways.

In summary, we demonstrated that prolonged exposure to fatty acids, which induces oxidative stress in islets, decreases beta cell function both in vitro and in vivo via activation of IKK $\beta$. The novelty of our findings is the demonstration that IKK $\beta$ mediates beta cell dysfunction induced by NEFA selectively, and that the IKK $\beta / \mathrm{NFKB}$ pathway is a therapeutic target to prevent NEFA-induced beta cell dysfunction in vivo.

Acknowledgements The authors thank L. Lam, Department of Physiology, University of Toronto, for her excellent technical assistance.

Data availability The datasets generated during and/or analysed during the current study are available from the corresponding author on reasonable request.

Funding This work was supported by Canadian Institutes of Health Research grants MOP-69018 (AG). AI was supported by Novo Nordisk Scholarships from the Banting and Best Diabetes Centre (University of Toronto) and Ontario Graduate Scholarships. AIO was supported by Novo Nordisk Scholarships from the Banting and Best Diabetes Centre (University of Toronto). KK was supported by scholarships from the
Banting and Best Diabetes Centre (University of Toronto), Ontario Graduate Scholarship, and Ontario Graduate Scholarship for Science and Technology. YM was funded by a Showa University Research Grant for Young Researchers.

Duality of interest The authors declare that there is no duality of interest associated with this manuscript.

Contribution statement $\mathrm{AI}, \mathrm{AIO}$ and $\mathrm{KK}$ researched and analysed data and drafted the manuscript. YM, JAE, LZ, RNF and JE researched and analysed data and contributed to revising the manuscript. GFL, MYD, MK, MBW, JE, AV and CBC contributed to data analysis and interpretation and reviewed and edited the manuscript. AG designed the study, contributed to the discussion and reviewed and finalised the manuscript. All the authors gave final approval to the submission of the manuscript. AG is the guarantor of this work and is responsible for the integrity of the work as a whole.

\section{References}

1. Giacca A, Xiao C, Oprescu AI, Carpentier AC, Lewis GF (2011) Lipid-induced pancreatic $\beta$-cell dysfunction: focus on in vivo studies. Am J Physiol Endocrinol Metab 300:E255-E262

2. Oprescu AI, Bikopoulos G, Naassan A et al (2007) Free fatty acidinduced reduction in glucose-stimulated insulin secretion: evidence for a role of oxidative stress in vitro and in vivo. Diabetes 56:29272937

3. Xiao C, Giacca A, Lewis GF (2008) Oral taurine but not Nacetylcysteine ameliorates NEFA-induced impairment in insulin sensitivity and beta cell function in obese and overweight, nondiabetic men. Diabetologia 51:139-146

4. Norlin S, Ahlgren U, Edlund $\mathrm{H}$ (2005) Nuclear factor-kB activity in $\beta$-cells is required for glucose-stimulated insulin secretion. Diabetes 54:125-132

5. Giannoukakis N, Rudert WA, Trucco M, Robbins PD (2000) Protection of human islets from the effects of interleukin-1 by adenoviral gene transfer of an IK $\mathrm{B} \alpha$ repressor. J Biol Chem 275: 36509-36513

6. Gao Z, Hwang D, Bataille F et al (2002) Serine phosphorylation of insulin receptor substrate 1 by inhibitor kappa B kinase complex. J Biol Chem 277:48115-48121

7. Zeender E, Maedler K, Bosco D, Berney T, Donath MY, Halban PA (2004) Pioglitazone and sodium salicylate protect human $\beta$-cells against apoptosis and impaired function induced by glucose and interleukin-1 $\beta$. J Clin Endocrinol Metab 89:5059-5066

8. Kharroubi I, Ladrière L, Cardozo AK, Dogusan Z, Cnop M, Eizirik DL (2004) Free fatty acids and cytokines induce pancreatic beta cell apoptosis by different mechanisms: role of nuclear factor- $\mathrm{\kappa} B$ and endoplasmic reticulum stress. Endocrinology 145:5087-5096

9. Rakatzi I, Mueller H, Ritzeler O, Tennagels N, Eckel J (2004) Adiponectin counteracts cytokine- and fatty acid-induced apoptosis in the pancreatic beta cell line INS-1. Diabetologia 47:249-258

10. Koutsari C, Jensen MD (2006) Thematic review series: patient-oriented research. Free fatty acid metabolism in human obesity. J Lipid Res 47:1643-1650

11. Yin MJ, Yamamoto Y, Gaynor RB (1998) The anti-inflammatory agents aspirin and salicylate inhibit the activity of IKB kinase- $\beta$. Nature 396:77-80

12. Maedler K, Oberholzer J, Bucher P, Spinas GA, Donath MY (2003) Monounsaturated fatty acids prevent the deleterious effects of palmitate and high glucose on human pancreatic beta cell turnover and function. Diabetes 52:726-733 
13. Ortsäter H, Sundsten T, Lin JM, Bergsten P (2007) Evaluation of the SELDI-TOF MS technique for protein profiling of pancreatic islets exposed to glucose and oleate. Proteomics 7:3105-3115

14. Burke JR, Pattoli MA, Gregor KR et al (2003) BMS-345541 is a highly selective inhibitor of I kappa B kinase that binds at an allosteric site of the enzyme and blocks NF- $\mathrm{KB}$-dependent transcription in mice. J Biol Chem 278:1450-1456

15. Mason TM, Goh T, Tchipashvili V et al (1999) Prolonged elevation of plasma free fatty acids desensitizes the insulin secretory response to glucose in vivo in rats. Diabetes 48:524-530

16. Kim S, Millet I, Kim HS et al (2007) NF-K B prevents beta cell death and autoimmune diabetes in NOD mice. Proc Natl Acad Sci U S A 104:1913-1918

17. Maeda S, Chang L, Li ZW, Luo JL, Leffert H, Karin M (2003) IKK $\beta$ is required for prevention of apoptosis mediated by cellbound but not by circulating TNF $\alpha$. Immunity 19:725-737

18. Dobbins RL, Szczepaniak LS, Myhill J et al (2002) The composition of dietary fat directly influences glucose-stimulated insulin secretion in rats. Diabetes 51:1825-1833

19. Park E, Wong V, Guan X, Oprescu AI, Giacca A (2007) Salicylate prevents hepatic insulin resistance caused by short-term elevation of free fatty acids in vivo. J Endocrinol 195:323-331

20. Koulajian K, Ivovic A, Ye K et al (2013) Overexpression of glutathione peroxidase 4 prevents beta cell dysfunction induced by prolonged elevation of lipids in vivo. Am J Physiol Endocrinol Metab 305:E254-E262

21. Moussy F, Velho G, Aubert N et al (1988) Absence of effect of heparin on insulin secretion. Artif Organs 12:137-142

22. Noel RJ, Antinozzi PA, McGarry JD, Newgard CB (1997) Engineering of glycerol-stimulated insulin secretion in islet beta cells. Differential metabolic fates of glucose and glycerol provide insight into mechanisms of stimulus-secretion coupling. J Biol Chem 272:18621-18627

23. Ehses JA, Meier DT, Wueest S et al (2010) Toll-like receptor 2deficient mice are protected from insulin resistance and beta cell dysfunction induced by a high-fat diet. Diabetologia 53:1795-1806

24. Tang C, Naassan AE, Chamson-Reig A et al (2013) Susceptibility to fatty acid-induced $\beta$-cell dysfunction is enhanced in prediabetic diabetes-prone biobreeding rats: a potential link between $\beta$-cell lipotoxicity and islet inflammation. Endocrinology 154:89-101

25. Castaño E, Bartrons R, Gil J (2000) Inhibition of cyclooxygenase-2 decreases DNA synthesis induced by platelet-derived growth factor in Swiss 3T3 fibroblasts. J Pharmacol Exp Ther 293:509-513

26. Smith CJ, Zhang Y, Koboldt CM et al (1998) Pharmacological analysis of cyclooxygenase-1 in inflammation. Proc Natl Acad Sci U S A 95:13313-13318

27. DeFronzo RA, Tobin JD, Andres R (1979) Glucose clamp technique: a method for quantifying insulin secretion and resistance. Am J Phys 237:E214-E223

28. Kahn SE, Prigeon RL, McCulloch DK et al (1993) Quantification of the relationship between insulin sensitivity and beta cell function in human subjects. Evidence for a hyperbolic function. Diabetes 42: 1663-1672

29. Hawley SA, Fullerton MD, Ross FA et al (2012) The ancient drug salicylate directly activates AMP-activated protein kinase. Science 336:918-922

30. Wu X, Mahadev K, Fuchsel L, Ouedraogo R, Xu SQ, Goldstein BJ (2007) Adiponectin suppresses IkappaB kinase activation induced by tumor necrosis factor-alpha or high glucose in endothelial cells: role of cAMP and AMP kinase signaling. Am J Physiol Endocrinol Metab 293:E1836-E1844

31. Morizane Y, Thanos A, Takeuchi K et al (2011) AMP-activated protein kinase suppresses matrix metalloproteinase- 9 expression in mouse embryonic fibroblasts. J Biol Chem 286:16030-16038
32. Tran POT, Gleason CE, Robertson RP (2002) Inhibition of interleukin-1beta-induced COX-2 and EP3 gene expression by sodium salicylate enhances pancreatic islet beta cell function. Diabetes 51:1772-1778

33. Henningsson R, Salehi A, Lundquist I (2002) Role of nitric oxide synthase isoforms in glucose-stimulated insulin release. Am J Phys Cell Physiol 283:C296-C304

34. Fontés G, Zarrouki B, Hagman DK et al (2010) Glucolipotoxicity age-dependently impairs beta cell function in rats despite a marked increase in beta cell mass. Diabetologia 53:2369-2379

35. Piatti PM, Monti LD, Baruffaldi L et al (1995) Effects of an acute increase in plasma triglyceride levels on glucose metabolism in man. Metabolism 44:883-889

36. Maedler K, Sergeev P, Ris F et al (2002) Glucose-induced beta cell production of IL- $1 \beta$ contributes to glucotoxicity in human pancreatic islets. J Clin Invest 110:851-860

37. Böni-Schnetzler M, Boller S, Debray S et al (2009) Free fatty acids induce a proinflammatory response in islets via the abundantly expressed interleukin-1 receptor I. Endocrinology 150:5218-5229

38. Eguchi K, Manabe I, Oishi-Tanaka Y et al (2012) Saturated fatty acid and TLR signaling link $\beta$ cell dysfunction and islet inflammation. Cell Metab 15:518-533

39. Xiao C, Giacca A, Lewis GF (2009) The effect of high-dose sodium salicylate on chronically elevated plasma nonesterified fatty acidinduced insulin resistance and beta cell dysfunction in overweight and obese nondiabetic men. Am J Physiol Endocrinol Metab 297: E1205-E1211

40. Fernández-Real JM, López-Bermejo A, Ropero AB et al (2008) Salicylates increase insulin secretion in healthy obese subjects. J Clin Endocrinol Metab 93:2523-2530

41. Chen M, Robertson RP (1978) Restoration of the acute insulin response by sodium salicylate. A glucose dose-related phenomenon. Diabetes 27:750-756

42. Giugliano D, Cozzolino D, Ceriello A et al (1988) Studies on the mechanism of salicylate-induced increase of insulin secretion in man. Diabete Metab 14:431-436

43. Mitchell JA, Akarasereenont P, Thiemermann C, Flower RJ, Vane JR (1993) Selectivity of nonsteroidal antiinflammatory drugs as inhibitors of constitutive and inducible cyclooxygenase. Proc Natl Acad Sci U S A 90:11693-11697

44. Fu A, Eberhard CE, Screaton RA (2013) Role of AMPK in pancreatic beta cell function. Mol Cell Endocrinol 366:127-134

45. Okazaki Y, Eto K, Yamashita T et al (2010) Decreased insulin secretion and accumulation of triglyceride in beta cells overexpressing a dominant-negative form of AMP-activated protein kinase. Endocr J 57:141-152

46. Surwit RS, Kuhn CM, Cochrane C, McCubbin JA, Feinglos MN (1988) Diet-induced type II diabetes in C57BL/6J mice. Diabetes 37:1163-1167

47. Wasner HK, Weber S, Partke HJ, Amini-Hadi-Kiashar H (1994) Indomethacin treatment causes loss of insulin action in rats: involvement of prostaglandins in the mechanism of insulin action. Acta Diabetol 31:175-182

48. Kulkarni RN, Brüning JC, Winnay JN, Postic C, Magnuson MA, Kahn CR (1999) Tissue-specific knockout of the insulin receptor in pancreatic beta cells creates an insulin secretory defect similar to that in type 2 diabetes. Cell 96:329-339

49. Hughes JH, Easom RA, Wolf BA, Turk J, McDaniel ML (1989) Interleukin 1-induced prostaglandin E2 accumulation by isolated pancreatic islets. Diabetes 38:1251-1257

50. Tran PO, Gleason CE, Poitout V, Robertson RP (1999) Prostaglandin E(2) mediates inhibition of insulin secretion by interleukin-1 $\beta$. J Biol Chem 274:31245-31248 